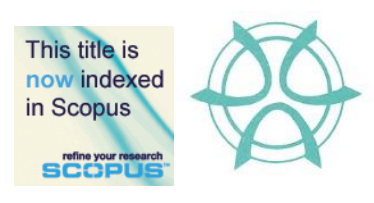

PLANNING MALAYSIA:

Journal of the Malaysian Institute of Planners

VOLUME 17 ISSUE 2 (2019), Page 1 - 12

\title{
CLEANLINESS INSPECTION OF THE ABLUTION SPACES OF THE FEDERAL TERRITORY MOSQUE
}

\author{
Hayder Jawad Shakir Haraty ${ }^{1}$ \& Nangkula Utaberta ${ }^{2}$ \\ ${ }^{1,2}$ Faculty of Design and Architecture \\ UNIVERSITI PUTRA MALAYSIA
}

\begin{abstract}
Muslims go to mosques to congregate in prayers; some Malaysian mosques carry historical value, whereas some are simply fine works of art. The term "Iconic Mosque" has been defined by the Islamic Tourism Centre in Malaysia as "having a design which represents the modern architecture and the cultural identity of the country". Some evidence shows that the ablution spaces in Malaysian Mosques encountered many issues regarding their cleanliness. Three methods of study were used to analyse the Federal Territory Mosque ablution spaces: physical observation, architectural drawing analysis, and interview. The research aims to improve the cleanliness of the ablution areas by studying their design aspects. The study's significance is to evaluate the cleanliness of ablution spaces at the Federal Territory Mosque. The findings of this research revealed that using a natural ventilation system could significantly improve the cleanliness of the ablution areas if accompanied by a mechanical system. The investigation analysis discovered that a smaller ablution room design could result in an unhygienic space. The users' abuse is one of the crucial factors that impact the ablution room cleanliness.
\end{abstract}

Keywords: Architectural drawing analysis, Federal Territory Mosque, Malaysian iconic mosques, physical observation, space cleanliness and hygiene 
Hayder Jawad Shakir Haraty \& Nangkula Utaberta

Cleanliness Inspection of the Ablution Spaces of the Federal Territory Mosque

\section{INTRODUCTION}

Ablution is a ritual activity that requires a Muslim to clean specific parts of the body in a sequence, and it is required before each prayer (Zakaria, Salleh, Harun, $\&$ Rashid, 2015). Cleanliness is one of the essential aspects of Islam; it has physical and mental attributes for the human being. The wholesome concept of purity and cleanliness is one of the most important values that must be practised in order to form a healthy and dynamic community and environment (Rahim, 2005). The research of Hamid, Taib, Wahab and Alias (2015) summarised that Islam encourages environmental factors such as cleanliness, good hygiene, and proper maintenance of prayer spaces. Neglecting any of these can result in inadequate ventilation, bad odours, and in overall, unhealthy area. In any design or facility, proper ventilation, which includes exposure to sunlight, significantly improves a space's hygiene and sanitation (Kumar, 2015). These qualities are essential for any human environment, especially for spaces that include the use of water (Sapri, Muin, Sipan, \& Adjei Twum, 2014). An unclean space could be created by a lack of designer's knowledge about users' movement inside a mosque and its facilities (Das, Qureshi, Chowdhury, \& Alam, 2012). Therefore, the scope of this study focusses on analysing the design layout of the Federal Territory Mosque ablution rooms using three approaches: physical observation, architectural drawing analysis and interview. The investigation helps to evaluate the cleanliness of the ablution rooms in the case study. Understanding the drawing layout assists with calculating the floor area and openings to be compared to Uniformed Building By-Laws (UBBL). The interview provides enough information from the management and the expertise to highlight the current issue at the Federal Territory Mosque.

\section{RESEARCH BACKGROUND}

Zain et al. (2015) stated that Malaysian mosques require more attention in terms of cleanliness; urgent improvements are needed to improve their facilities. Moreover, environmental factors such as humidity and airflow are also determining prayer-space space hygiene because they can cause bad smells, fungi, and bacterial accumulation (Sapri et al., 2014). Another report by (Zulkifli, 2016) mentioned that Muslim communities should pay more attention to the ablution room's cleanliness and hygiene of mosques overall. There are several factors such as inexperienced workers and users' mistreatment that are also affecting the hygiene of the religious spaces. Moist ventilation and space accessibility have also been highlighted as an important factor of Malaysian mosques hygiene (Zain et al., 2015). Additionally, more investigation of the ablution rooms has found (Maher, 2016; Suhaimi, 2010) that the issue of ventilation is epidemic in Malaysian's mosques and has caused poor ventilation, black footprints, and repulsive ablution rooms. These result in public concern. Maher also stated that besides these issues, the location of the ablution room in a 
PLANNING MALAYSIA

dingy basement, poor ventilation, and improper treatment of space have also been reported by users. Other research (e.g. Haraty \& Utaberta, 2018) depicted an unclean ablution area during the peak of the congregational hour in one Malaysian iconic mosque. However, most of the studies have dealt with smaller ablution spaces and suraus $^{l}$; there is a lack of research that investigates the cleanliness of the ablution rooms in grand mosques in Malaysia. The study recommends further inspection regarding the ablution areas in the Malaysian iconic mosques.

\section{METHODOLOGY}

This study uses a qualitative approach that involves physical observation, architectural drawing analysis, and interviews. According to the Ministry of Tourism, Art and Culture Malaysia (MOTAC) and the Islamic Tourism Centre (ITC), there are 53 Malaysian mosques considered to be iconic mosques in Malaysia (Islamic Tourism Centre, 2013). Yin (2013) explained that the way to find proper case studies for any research is to have a sufficient amount of data that can be accessible. The research sample was taken from this group. Capturing visual records during fieldwork can provide rich information for the research. Visual images can be part of the research and its method of data collection sometimes (Payne \& Payne, 2004). Architectural drawing analysis is the method of extracting information from drawings that helps to analyse the shape and the size of the sample (Dosch, Tombre, Ah-Soon, \& Masini, 2000; Roosli, O'Keefe, \& Mydin, 2013).

\section{Physical Observation}

The researcher observed one iconic mosque in Malaysia, which is the Federal Territory Mosque. The investigation included three ablution rooms, which were at Gate-A, B, and C. The physical observation includes inspecting the condition of the ablution areas' cleanliness. It also involves investigating the type of ventilation system used, which has a direct impact on hygiene.

\section{Architectural Drawing Analysis}

Architecture drawing analysis includes studying the design form by hand sketching the selected ablution spaces. A software application AutoCAD was used to demonstrate the spatial organisation of the ablution areas. Uniform Building By-Laws (UBBL) are used to compare the findings from architectural analysis to the Malaysian standards. Architectural drawing analysis is further used to understand if the ablution spaces have achieved the minimum requirement, which is not less than $10 \%$ of the total floor area for space with a natural ventilation system as stipulated in the Uniform Building By-Law 1984

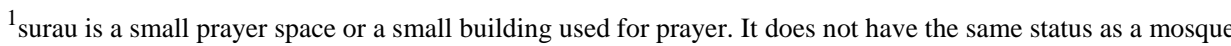


Hayder Jawad Shakir Haraty \& Nangkula Utaberta

Cleanliness Inspection of the Ablution Spaces of the Federal Territory Mosque

(UBBL). The following equation is used to compare the results from the architectural drawing analysis to UBBL:

$\frac{\text { Total area of openings (natural ventilation) }}{\text { Total floor area of the ablution area }} \geq 10 \%$ of the floor area

\section{Structured Interview}

Boyce \& Neale (2006) stated that conducting structured interviews is usually done with a small number of respondents to explore their perspectives regarding an issue or situation. A structured interview is a qualitative type of research technique, and it helps to generate understanding about an existing issue and evaluate a specific phenomenon by transcribing, analysing, and planning a good interview (Mason, 2002). An interview ${ }^{1}$ was conducted with the management office of the Federal Territory Mosque to understand the obstacles and complications regarding the ablution rooms.

\section{FEDERAL TERRITORY MOSQUE}

The construction of this mosque started in 1996 and was completed in 2000. It has been serving Muslims as a community centre, research and educational complex. It is located near the MATRADE building and Jalan Duta's government complex. The Sultan Ahmed Mosque in Turkey influences the mosque design. A combination of traditional Malay and Middle East design elements are also implemented in the design.

\section{Physical Observation}

The investigation was conducted on three different days: February $21^{\text {st }}$, and the $3^{\text {rd }}$ and $5^{\text {th }}$ of March 2018 and covered three ablution areas: Gate-A, Gate-B, and Gate-C. The complexity of the design of this mosque was evident during the physical observation. The ablution areas are scattered around four gates and designed in smaller spaces.

During the usual hours, the mosque was not crowded. It was noticed that all users are required to remove their shoes at the entrance gates to show their respect and for cleanliness purposes. Worshippers must walk barefoot inside the mosque and the ablution areas. Ablution Gate-A was the first one to be examined in this research; the location of the ablution area is close to the women's toilet area, which has a direct impact on the smell of the ablution room. A person can undoubtedly smell the odour coming from the toilet. According to the observation, the ablution areas use both mechanical and natural ventilation. Extractor fans have been installed on some sides of the walls. Although all

\footnotetext{
${ }^{1}$ The interview questions which were given to the participant are available upon request 
PLANNING MALAYSIA

Journal of the Malaysia Institute of Planners (2019)

ablution rooms have artificial lighting, natural light during the day is sufficient. Moreover, the Gate-A ablution room has 22 windows that provide the room with natural sunlight and airflow. The ablution room also has a few ceiling fans and extraction fans to maximize ventilation inside the space. The location of this ablution room is important because it is very close to the prayer hall. The researcher captured the following photographs during the physical observation of the mosque. The photographs show the entrance of Gate-A ablution room and the interior of the room.
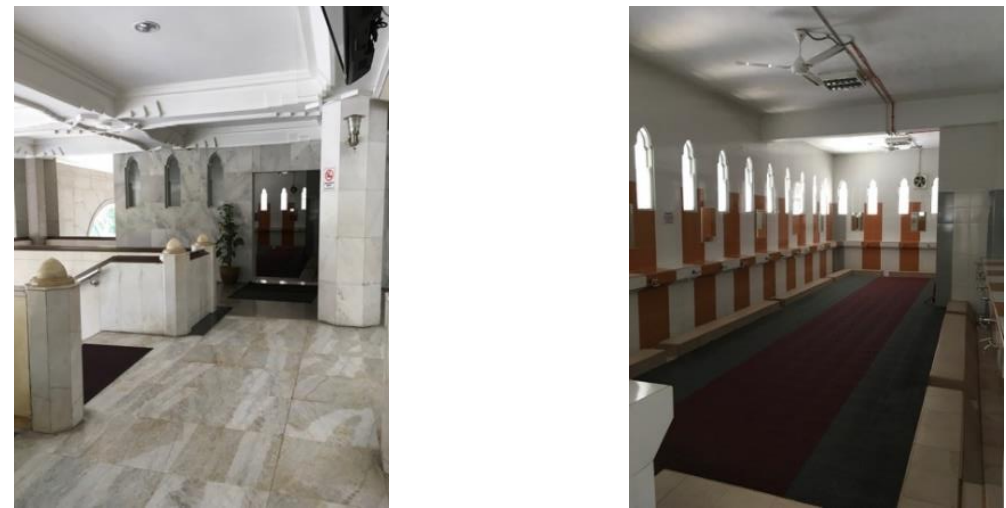

Figure 1 Natural ventilation of Gate-A ablution room Source: Author

The Gate-B ablution room uses a natural ventilation system. During the inspection, animal waste was spotted on the floor of the ablution room. The trash bin was placed with no attention to its cleanliness; many insects such as flies, and cockroaches were spotted. Additionally, the area was smelly, resulting from the animal waste. There were dark spots on the floor of the ablution room which can easily be traced. The design of the room and the location provides this space with enough access to natural ventilation. This ablution area is close to the main entrance, and the design of the walls are fully penetrating the exterior of the mosque. No obstacles like a door on any other elements block the airflow inside the space. 
Hayder Jawad Shakir Haraty \& Nangkula Utaberta

Cleanliness Inspection of the Ablution Spaces of the Federal Territory Mosque

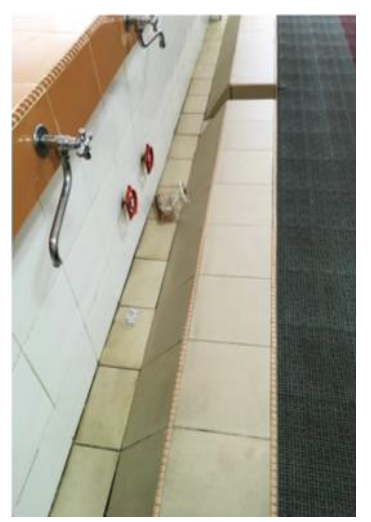

Figure 2 The condition of Gate-B ablution room Source: Author

However, few mechanical ventilation ducts are installed in this room. The ducting system was not well maintained. It was dusty and unclean, as shown in Figure 3. In addition, the water drain area needs further cleaning because it showed unhygienic signs such as water stains, trash, and fungus.
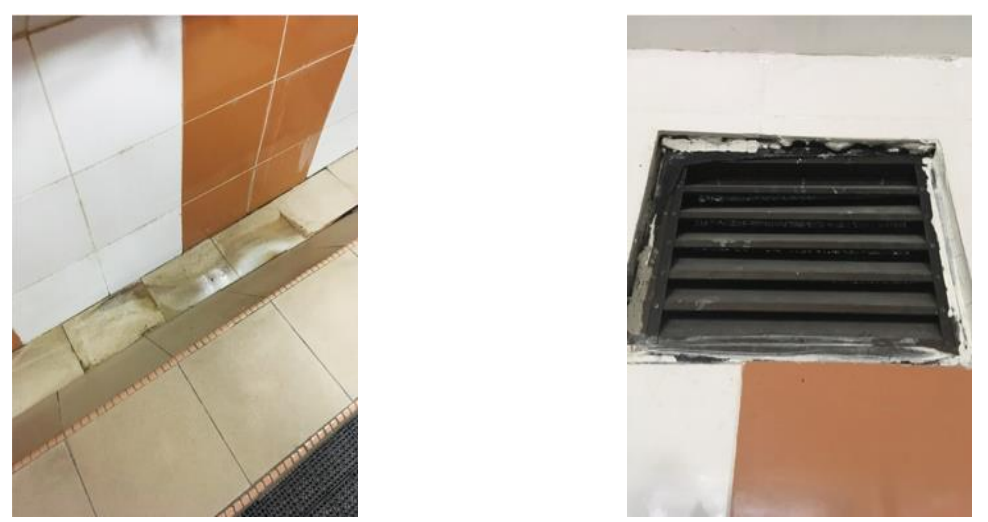

Figure 3 Unclean ducting system and stained floor, ablution room Gate-B Source: Author

Additionally, the ablution area located close to Gate-C had no ventilation system, neither natural nor mechanical. A lattice side wall with decorative elements is the only opening in this room, which looks into the indoor corridor of the mosque. Gate-C needs extra attention; the inspection revealed issues like dark spots, shabby flooring, and stained walls. Furthermore, the investigation during the daylight showed that without the use of artificial lights, the space is dark and not well ventilated. 

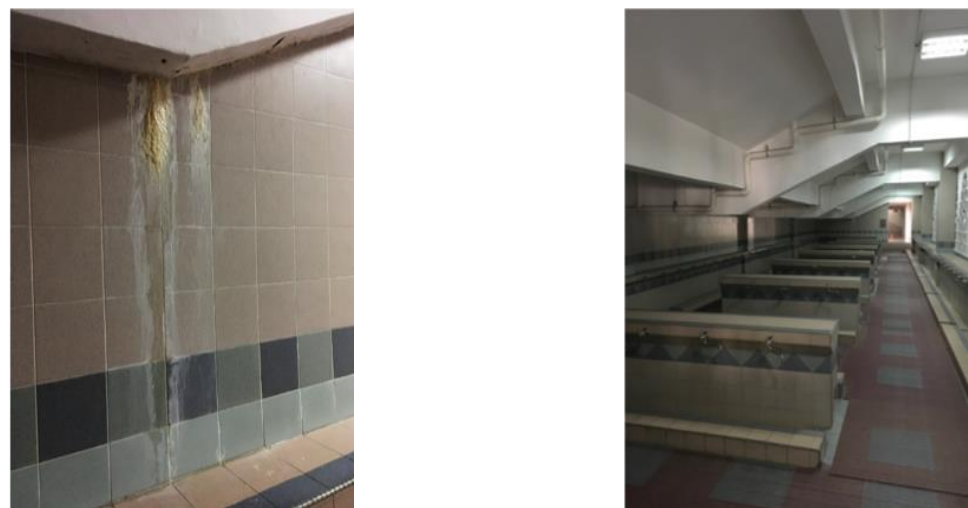

Figure 4 The situation of ablution room Gate-C with no ventilation system Source: Author

\begin{abstract}
ARCHITECTURAL DRAWING ANALYSIS
This part of the analysis involved systematic steps in redrawing the layout of each ablution room. The researcher manually sketched the layout of the ablution rooms after conducting the physical observation to get the actual dimensions of each of them. The results from the measurements would significantly assist in generating more accurate architecture drawings. The architectural drawing is then transformed into digital records by utilising AutoCAD software. This is done to compare the result of the total area of each ablution room to the UBBL, which is $10 \%$ of the total floor area. The following analysis is the findings of the three ablution rooms.
\end{abstract}

\title{
Gate-A Ablution Room
}

This area is located between two areas and is connected by two stairs that lead to the prayer hall and the ground floor. It is the most accessible room for worshipers because it is close to the prayer hall. The ablution room is $12.5 \times 5.0$ metres and has 62.5 square metres. There are 22 windows with $1.14 \times 0.35$ metres and covering 8.778 square metres. The entrance is $2 \times 3.9=7.8$ square metres and a total of 16.5 square metres. The formula $16.5 / 62.5=0.264$ achieves the required percentage by UBBL. 
Hayder Jawad Shakir Haraty \& Nangkula Utaberta

Cleanliness Inspection of the Ablution Spaces of the Federal Territory Mosque

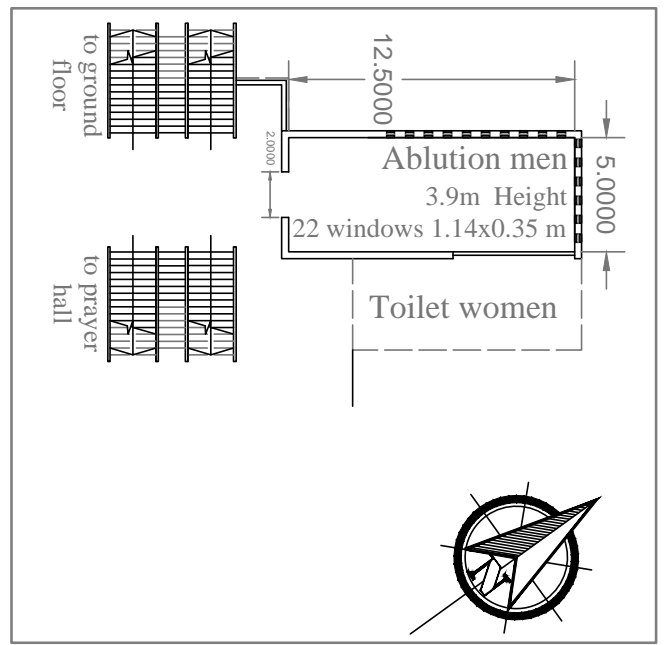

Drawing 1 Gate-A Ablution room Source: Author

\section{Gate-B Ablution Room}

This ablution room is close to Gate-B and is around 60 metres far, its design could be one of the suitable rooms in term of area. However, there are no stairs that lead to the prayer hall. A person is required to walk along the corridor to the stairs area. The area of the ablution room can be calculated as following: $(20 \times 8.77)+$ $(10 \times 8.6)=261.4$ square metres, the area of the opening is as the following: windows $((22.85 \times 2)+(8.6 \times 2))+$ doors $((1.4 \times 2.85)+(1.4 \times 3))=44.49$ square metres. The percentage of the opening to the total area is $44.49 / 261.4=0.170$, which is above the requirement by UBBL.

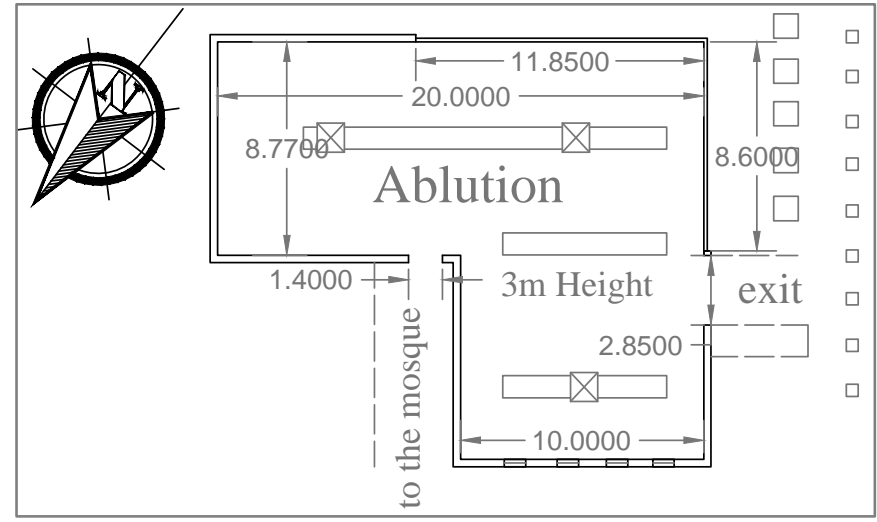

Drawing 2 Gate-B Ablution room Source: Author 


\section{Gate-C ablution room}

Results show that this room is one of the more questionable ablution rooms in this case study. The room is located beneath the prayer hall with two main stairs connecting it. There were no windows nor access to natural ventilation designed for it (see physical observation part). The area was calculated as follows: $30 \mathrm{~m} \mathrm{x}$ $7.60 \mathrm{~m}=228$ square metres, the area of the doors is $2 \times(2 \mathrm{~m} \times 1.65 \mathrm{~m})=8.91$ square metres. The percentage is $8.91 / 228=0.039$, which means it does not achieve the minimum percentage required by UBBL.

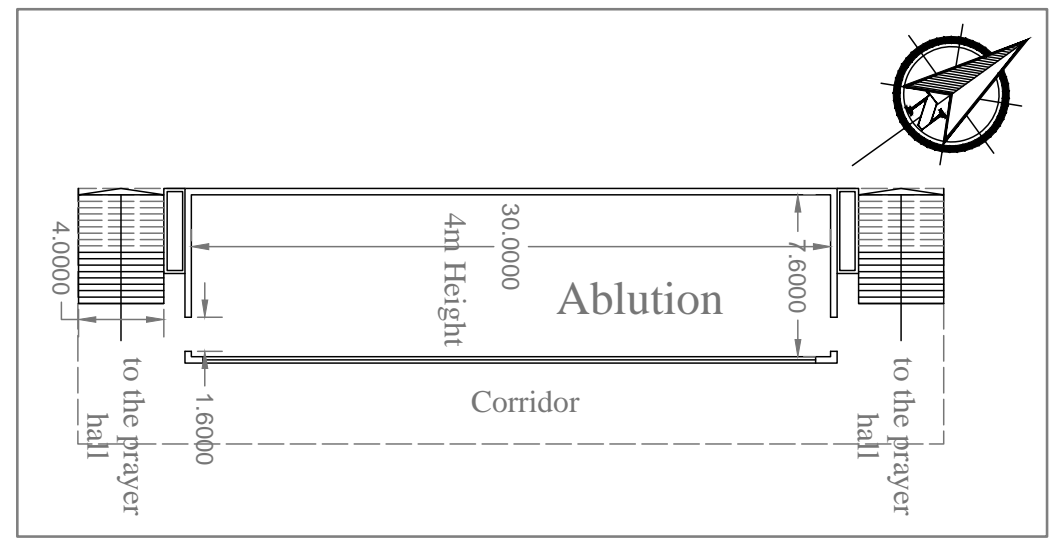

Drawing 3 Gate-C Ablution room

Source: Author

\section{Interview}

An interview was conducted with Participant $1^{1}$, who is one of the management staff at Masjid Wilayah, on March 3, 2018. The participant manages and supervises the mosque's facilities. The following statement was given during the interview:

The ablution areas are using a natural ventilation; however, some mechanical blowers and fans will be used to dry up the area. It was mentioned that mixing between the natural ventilation system and the mechanical systems is recommended to speed up the drying process. Moreover, during the peak hour, the situation of the ablution area is terrible, and the cleaning is not enough. The ablution area gets overcrowded in the Friday congregation prayers. The other issue is the lack of cleaning staff. We had to let go half of the cleaning members to cut the budget of the mosque. The official working hours for the mosque's staff

\footnotetext{
1 The interviewee requested not to show a name in any publication; however, you may contact the corresponding author for verification
} 
Hayder Jawad Shakir Haraty \& Nangkula Utaberta

Cleanliness Inspection of the Ablution Spaces of the Federal Territory Mosque

is from the early morning to 4:30 p.m., so there are no workers during the night prayer. Some other mosques have volunteered to offer two cleaners to help out the situation. There had been some issues regarding the users' mistreatment of the ablution areas. One problem is that users are throwing trash onto the floor. There have been other incidents where they urinate in the ablution area or even defecate. It was recommended to separate the toilet area and the ablution area for hygiene purpose. Another issue is that there are no standards for the ablution area cleaning and cleanliness. Mostly the instruction is given by the management and the mosque staff. The fact is the ablution area belongs to the mosque and people. Therefore, it should be treated carefully.

\section{DISCUSSION OF THE FINDINGS}

The Federal Territory Mosque or "Masjid Wilayah" is one of the most challenging cases to study. The designer intended to have smaller ablution rooms distributed between four gates namely. This distribution of the ablution spaces is to cover each gate. Although the designer placed several ablution rooms to cover the area of the mosque, the overall cleanliness was questionable. Moreover, the ablution rooms are using natural ventilation system, and fewer fans are installed to increase the airflow. Among the issues of the ablution areas of Masjid Wilayah is the smell. The physical observation revealed this crucial issue in the three spaces observed. Likewise, the cleanliness of the ablution rooms was also below standards. Footprints covering the floor, leakage of water, fungus and insects are among the critical issues. Additionally, the findings from the architectural drawing analysis discovered that only two ablution areas meet the UBBL standards, which are Gate-A and Gate-B. Conclusively, the interview part of the analysis contributed significantly to the findings of this case study. Participant 1 addressed some critical points that need to be addressed urgently. Among the issues are limited working hours, insufficient cleaners, users' mistreatment, and improper design.

\section{CONCLUSION}

To summarize, although a natural ventilation system is a proper mechanism for spaces that involve using water, it is recommended to use separated mechanical blowers during the peak hours to increase the efficiency of the ventilation. The other important point is the users' mistreatment. It is crucial to share the awareness among worshippers and users to comply with the hygiene considerations of the ablution area spaces. The ablution areas are sacred spaces which should be appropriately treated to respond to the Islamic teaching and the health requirement. Lastly, designers should provide the ablution areas or any spaces using water with enough ventilation systems to prevent any future diseases that could result from improper planning. Authorities should pay more attention 
to provide enough regulations and standards to generate healthier spaces that respond to users' needs.

\section{ACKNOWLEDGEMENTS}

This research was partially supported by Geran Universiti Putra Malaysia / Putra Graduate Initiative (IPS). We thank anonymous reviewers for their comments on an earlier version of the manuscript.

\section{REFERENCES}

Boyce, C., \& Neale, P. (2006). Conducting in-depth interview: A guide for designing and conducting in-depth interviews. Pathfinder International Tool Series, Monitoring and Evaluation-2.

Das, R., Qureshi, T., Chowdhury, M., \& Alam, M. (2012). Health factors in Islamic perspectives and its relation to sustainability with case study at traditional and modern mosque. Journal of Environmental Science and Natural Resources, 5(1), 49-63.

Dosch, P., Tombre, K., Ah-Soon, C., \& Masini, G. (2000). A complete system for the analysis of architectural drawings. International Journal on Document Analysis and Recognition, 3(2), 102-116.

Hamid, A.B.A., Taib, M. Z. M., Wahab, M. H. A., \& Alias, A. (2015). The design and environmental aspects of the prayer room. In R. Omar, H. Bahrom, \& G. D. Mello (Eds.), Islamic perspectives relating to business, arts, culture and communication: Proceedings of the 1st ICIBACC 2014 (pp. 1-9). Basingstoke, England: Springer.

Haraty, H. J. S., \& Utaberta, N. (2018). An inspection of the ablution room from cleanliness perspective: Case study of Federal Territory Mosque. In 2nd Mini Symposium on Islamic Tourism 2018. April 19-20, 2018, Kuala Lumpur, Malaysia.

Islamic Tourism Centre. (2013). Mosque trails in Malaysia: A showcase of 57 iconic mosques from 14 states rich in history and majestic architecture. Kuala Lumpur: Ministry of Tourism \& Culture, Malaysia. Available at www.itc.gov.my

Kumar, G. (2015). Environment sanitation and building design. International Journal for Innovative Research in Science \& Technology, 2(07), 71-76.

Maher, H. (2016). Suraus in shopping malls: A holy place neglected by Malaysians. Retrieved from http://www.malaysiandigest.com/frontpage/282-main-tile/639295suraus-in-shopping-malls-a-holy-place-neglected-by-malaysians.html

Mason, J. (2002). Qualitative researching (Second). London: SAGE Publications.

Payne, G., \& Payne, J. (2004). Key concepts in social research. Thousand Oaks, CA: SAGE.

Rahim, A. A. (2005). A concept of clean toilet from the Islamic perspective. Journal of Islamic Built Environment, 1(1), 71-84.

Roosli, R., O'Keefe, P., \& Mydin, A. O. (2013). Evolution of disaster planning and housing in Malaysia: A reviews. World Applied Sciences Journal, 21(7), 945-959.

Sapri, M., Muin, Z. A., Sipan, I., \& Adjei Twum, A. (2014). Barriers in managing mosque facilities: Towards sustainable facilities management approach. International Real Estate Research Symposium 2014 (IRERS 2014), 1-8.

Suhaimi, M. (2010). Kerja-kerja mencuci bilik wuduk \& tandas surau. Retrieved from https://www.jmbpks7.com.my/kerja-kerja-mencuci-bilik-wuduk-tandas-surau/ 
Hayder Jawad Shakir Haraty \& Nangkula Utaberta

Cleanliness Inspection of the Ablution Spaces of the Federal Territory Mosque

Uniform Building By-Laws 1984 (Malaysia).

Yin, R. K. (2013). Case study research: Design and methods. Thousand Oaks, CA: SAGE.

Zain, A. M., Saberi, N. E., Jaafar, F., Fauz, F. H. A., Ramli, W. N. R. W., \& Lugiman, F. A. (2015). International Colloquium of Art and Design Education Research (iCADER 2014). Singapore: Springer.

Zakaria, A. Z., Salleh, I. H., Harun, S. N., \& Rashid, M. S. A. (2015). International Colloquium of Art and Design Education Research (i-CADER 2014). Singapore: Springer.

Zulkifli, H. Z. Z. (2016). Pakai sendal jepit, pegang sikat, Zola bersihkan tempat wudhu Mesjid Agung Al-Falah. Retrieved from https://infojambi.com/zumi-zola-bersihkanmesjid-agung-al-falah/

Received: $12^{\text {th }}$ January 2019. Accepted: $2^{\text {nd }}$ August 2019 